\title{
THEORY OF EVAPOTRANSPIRATION
}

\section{Soil and intercepted water evaporation}

\author{
ANATOLIJ IVANOVIČ BUDAGOVSKYI ${ }^{1 \dagger}$, VILIAM NOVÁK ${ }^{2)}$ \\ ${ }^{1)}$ Institute of Water Problems, Russian Academy of Sciences, Gubkina St. 3, 117971 Moscow, Russian Federation. \\ ${ }^{2)}$ Institute of Hydrology, Slovak Academy of Sciences, Racianska 75, 83102 Bratislava, Slovak Republic, Europe; \\ Mailto: novak@uh.savba.sk
}

Evaporation of water from the soil is described and quantified. Formation of the soil dry surface layer is quantitatively described, as a process resulting from the difference between the evaporation and upward soil water flux to the soil evaporating level. The results of evaporation analysis are generalized even for the case of water evaporation from the soil under canopy and interaction between evaporation rate and canopy transpiration is accounted for. Relationships describing evapotranspiration increase due to evaporation of the water intercepted by canopy are presented. Indirect methods of evapotranspiration estimation are discussed, based on the measured temperature profiles and of the air humidity, as well as of the net radiation and the soil heat fluxes.

KEY WORDS: Evapotranspiration, Transpiration, Evaporation, Soil Water, Water Balance.

Anatolij Ivanovič Budagovskij, Viliam Novák: TEÓRIA EVAPOTRANSPIRÁCIE. 2. Vyparovanie vody z pôdy a intercepčne zachytenej vody. J. Hydrol. Hydromech., 59, 2011, 2; 22 lit., 4 obr.

Príspevok obsahuje kvantitatívny opis výparu vody z pôdy a bilanciu energie počas vyparovania, charakterizovanú rovnicou obsahujúcou turbulentný tok tepla a skupenské teplo vyparovania. Je opísaný proces tvorby suchej vrstvy na povrchu pôdy počas výparu; jeho tvorba závisí od rozdielu medzi rýchlost'ou výparu a prítokom vody k horizontu výparu zo spodnej vrstvy pôdy.Výsledky analýzy možno použit' aj na kvantifikáciu výparu z pôdy pod porastom. Uvádzajú sa vzt’ahy na výpočet zvýšenia rýchlosti evapotranspirácie, spôsobenej intercepciou. Práca obsahuje analýzu nepriamych metód výpočtu evapotranspirácie, ktoré sú založené na meraní profilov teploty a vlhkosti vzduchu nad vyparujúcim povrchom, ako aj radiačnej bilancie a tokov tepla $\mathrm{v}$ pôde.

KLÚČOVÉ SLOVÁ: evapotranspirácia, transpirácia, evaporácia, pôdna voda, bilancia vody.

\section{Soil water evaporation}

Kossovich (1904) was probably the first, who presented quantitative description of the soil water evaporation. He proposed the three stages of it. This proposal - with some limitations - is accepted even today.

The basic features of Kossovich's approach will be presented here, and those three stages of soil evaporation will be briefly discussed.

The first stage of evaporation is usually observed after the rainfall or the snowmelt. Duration of this stage is usually short with exception in the late autumn or in the early spring. It can be observed during the winter period without snow cover too. Necessary condition of the first stage of evapora- tion is the saturated humidity of the air layer closely adjacent to the soil surface.

First stage of evaporation rate depends on whole complex of the meteorological characteristics, and soil water transport to the soil surface limiting duration of this evaporation stage.

The second stage of evaporation starts with drying of the soil surface, and with deepening of evaporating soil horizon below the soil surface. During this stage, the evaporation rate does not depend upon meteorological conditions only, but the more important factor is the water flux rate to the evaporating layer. This stage of evaporation lasts to the moment when liquid phase of the soil water transport is negligibly small.

The third stage of evaporation takes place after stopping of the liquid phase water transport. Water 
vapour flux rate depends mostly on the meteorological conditions, but its rate is relatively low, in comparison to the both previously mentioned evaporation rates.

Up to the end of ninety forties, no results fundamentally contributing to the methods, enabling quantitaive description of the evaporation process have been published. The important and well known publication of Penman (1948) and some of its modifications appeared later. All of them are suitable for quantitative description of the soil water evaporation first stage only.

In 1957, an article of Philip and de Vries (1957) appeared, which inspired many soil physicists to the soil water regime problems. This study is based on simultaneous solution of equations describing water and heat transport in soils, and of the continuity equation. The aim of this work was the soil water content profile estimate, during the evaporation process. Influence of the meteorological conditions was introduced by given boundary conditions.

Analysis of this work, and further continuation in this research was conducted by Novak (1981). It was shown, that solution of those equations, and especially, difficulties in input parameters estimates, are the limiting factors in utilisation of this approach. The simplified method of these parameters estimation was presented, preserving the so called "diffusion" approach. Experiments were conducted in laboratory, under nearly stationary conditions (temperature, air humidity), making possible to evaluate the influence of the soil water characteristics hysteresis on the evaporation process.

From this short description of history and state of the art evaporation process description, it follows the need for further soil evaporation research, based on new ideas in this field. An idea about the three soil water evaporation stages can be utilised even now.

It is suitable to use results of similarrity theory for the stratified atmosphere by temperature. The influence of temperature stratification of an atmosphere on evaporation process can be neglected, because its influence is small for the $2 \mathrm{~m}$ air layer adjacent to the wet soil surface.

The next discussion will be based on equations, developed by Monin and Yaglom (1965):

$u_{2}=\frac{u_{*}}{\chi} \ln \frac{z_{2}}{z_{0}}$,

$$
\begin{aligned}
& T_{2}-T_{0}=T_{*} \ln \frac{z_{2}}{z_{0}}, \\
& q_{2}-q_{0}=q_{*} \ln \frac{z_{2}}{z_{0}}, \\
& T_{*}=-P / \chi c_{p} \rho u_{*}, \\
& q_{*}=-E / \chi \rho u_{*} .
\end{aligned}
$$

Here $u_{*}$ - dynamic velocity, $\chi$ - Kármán constant, $T_{*}$ and $q_{*}-$ dimensionless temperature and air humidity, respectively, subscripts " 2 " at $u, T$ and $q$ indicates the height (elevation above the base) of their measurements $z=2 \mathrm{~m}$, subscript " 0 " - characteristics were estimated on the upper boundary of the roughness layer, indicated as $z_{0}$.

The question of the air temperature and air humidity differences was not solved, starting with Prandtl, the author of semiempirical turbulence theory. Published hypotheses were verified, but without success. Zilitinkievic and Monin (1971) have shown, that the difference in temperature and humidity is proportional to the second root of the Reynolds number:

$T_{0}-T_{\mathrm{S}}=0.13 T_{*}\left(\frac{u_{*} z_{0}}{v}\right)^{0.5}$,

where $T_{\mathrm{s}}$ - soil surface temperature, $v$ - kinematic viscosity. Analogical relationship holds for the air humidity difference

$q_{0}-q_{\mathrm{S}}=0.13 q_{*}\left(\frac{u_{*} z_{0}}{v}\right)^{0.5}$.

Using the Eqs. (71) and (72), a relationship describing the first stage of soil evaporation can be developed. At first, we can express $T_{0}$ from (67) and (71), and then $q_{0}$ from equations (68) and (72). Then, the term for $T_{*}$ and $q_{*}$ will be used, and the Eq. (66) will be solved for $u_{*}$. Then, after simple rearrangements we can write

$$
\begin{aligned}
& P=D_{\mathrm{s}} \rho c_{p}\left(T_{\mathrm{s}}-T_{2}\right), \\
& L E=D_{s} L \rho\left(q_{\mathrm{s}}-q_{2}\right),
\end{aligned}
$$




$$
\begin{aligned}
& D_{\mathrm{s}}=c_{1} u_{2} /\left(1+c_{2} u^{1 / 2}\right) \\
& c_{1}=\chi /\left(\ln \frac{z_{2}}{z_{0}}\right) ; \\
& c_{2}=0.13\left(\frac{\chi z_{0}}{v}\right)^{1 / 2}\left(\ln \frac{z_{2}}{z_{0}}\right)^{2 / 3} .
\end{aligned}
$$

Fig. 9 shows the relationship $D_{\mathrm{s}}=f\left(u_{2}\right)$. Experimentally obtained points on it, were evaluated using the measured data $P, T_{2}, T_{s}$ and $u_{2}$, and the Eq. (73). $P$ value was estimated by the energy balance method, $T_{s}$ was measured by series of special thermometers, made of 18 thermocouples, which has made possible to estimate reliable averaged soil surface temperature. Significant dispersion of points is supposed to be due to special soil tillage methods used to prepare the field for cotton planting. As a result of the tillage mentioned, the roughness coefficient involved in $D_{s}$, depends significantly on the wind direction.

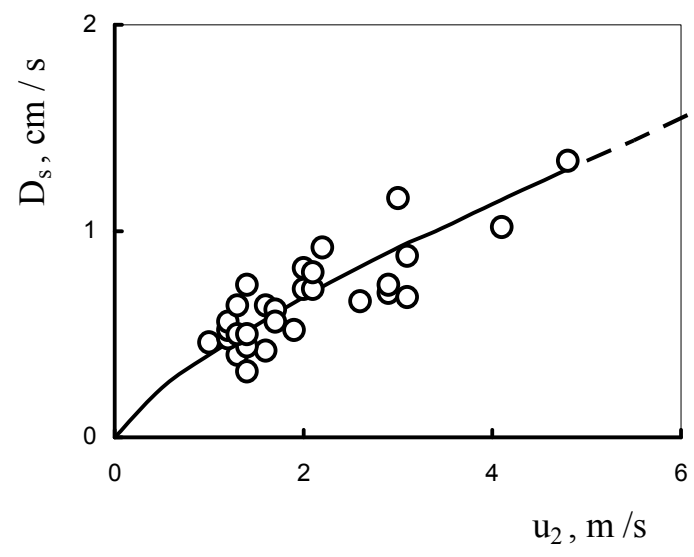

Fig. 9. Integral conductivity coefficient $D_{s}$ versus wind velocity $u_{2}$.

Air humidity $q_{s}$ in the Eq. (74) at temperature $T_{s}$ is saturated, therefore it seems to be reasonable to express it by the Magnus formula and by development of $q_{s}$ into series, taking into account the first two terms of them. Equation of the soil surface energy balance will be used too

$R_{\mathrm{S}}=L E_{\mathrm{s}}+P_{\mathrm{s}}-B$

As result of some simple transformations, the Eq. (77) was developed, which describes the first stage of evaporation from the soil surface

$$
L E_{s p}=L \rho b_{1} D_{s} d+b_{2}\left(R_{s}-B\right),
$$

where $b_{1}, b_{2}$ - coefficients (Eg. (85)).

Analysis of the water evaporation second stage can start from the hypothesis that the soil water content profile, during soil water transport at this stage, is a box - like type.

This kind of hypothesis - the box - like type of soil water transport, is not a traditional one. Therefore, it can be useful to analyze some of aspects of water infiltration into soil.

Budagovskyi (1955) described typical leading edge of the infiltration water, which is expressed as a distinctive, but sometimes of an irregular shape, changing with time considerably. The infiltration experiments were conducted with different kinds of soil, with different texture, and of different densities, located in the large diameter glass cylinders. Relationship between the infiltrated water quantity, and the infiltration front position, was found linear and a very close one. It can be mentioned, that the infiltrated water pressure head was fixed by the Mariotte bottle. Slope coefficient of the line describing this relationship was found as equal to the soil sample average water content increase rate.

Gusev (1981) presented results of laboratory experiments with water infiltration into the soil. The Hele - Shaw model was used in experiments. Its height was $180 \mathrm{~cm}$ and internal cross-section was $1 \times 20 \mathrm{~cm}$. Infiltration front position was fixed by photography. Results of those experiments are presented in Fig. 10a).

Soil water content profile (Fig. 10b)) was calculated using data of Fig. 10a). Relationship between quantity of the infiltrated water and position of the infiltration front (an average value in horizontal direction) for a given time was estimated. From the data presented it follows, that at leading edge of the infiltration front, it can be rather of a complicated shape. It has to be a discontinuous change of the soil water potential from zero to its initial value. The mentioned complicated shape of the infiltration front can result from the "filtration diffusion" effect, due to a significant spatial variability of pore dimensions, as well as to the irregularity of their interconections.

Shape of the soil water content profile, averaged in a horizontal level should be analogical to that presented in Fig. 10b), even if the soil water content is measured in a very thin layers. It seems to be probable, that it provoked an illusion about description of the infiltration of water into soil by the Richard's type of an equation, which is of a diffusion type. 
The second, widely accepted case of a frontal or better say - quasi frontal soil water transport in an unsaturated soil, is directly related to evaporation. Reason of this phenomenon is the capillary sorption hysteresis. Relation between the soil water potential and the soil water content is not unambiguous, and the hysteresis loop can be identified. A soil water content at the equilibrium during the drying process of the soil is higher at the same soil water potential as it is for the wetting soil. The maximum difference between them exert the boundary hysteresis curves, but there are other possibilities of changes inside those two boundary curves. The transition process is very slow one. Therefore, during the daily course of evaporation, it is difficult to be identified. The same can be also observed even for the inter-daily evaporation changes. (a)

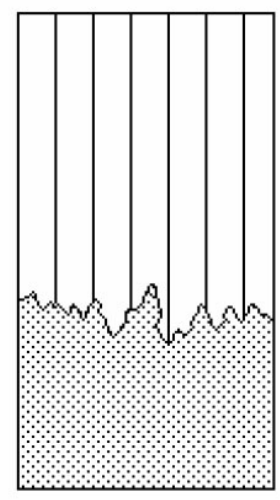

(b)

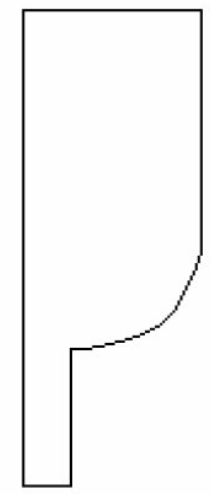

(c)

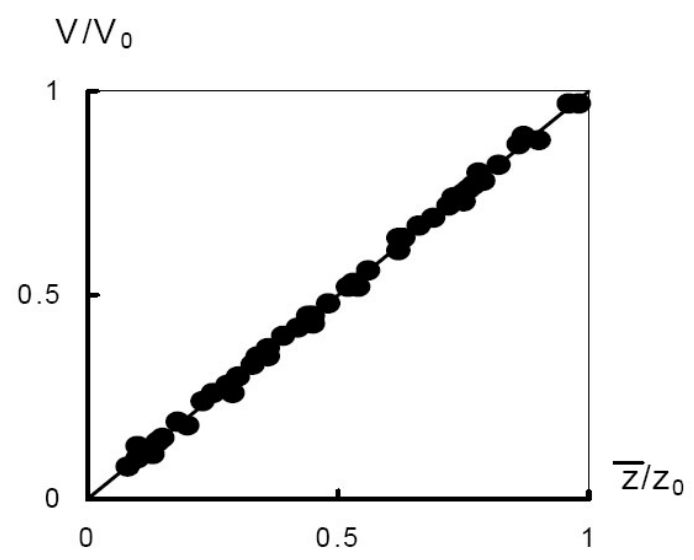

Fig. 10. Soil water content profile during infiltration of water into soil (a), soil water content profile during infiltration, averaged horizontally (b), and the relation between relative infiltrated water volume $V / V_{0}$, and the relative infiltration front depth $z / z_{0}$, where $z_{0}$ is the height of the soil column - (c).

Based on previous remarks, it can be stated, that the soil water transport during evaporation is of a front like - type. To avoid misunderstanding (hysteresis loop cannot be ignored), it will be better to use the word "quasifrontal" transport of soil water, having in mind, that this prefix "quasi" reflects more principal difference than the factual one.

Experimental evidence of the frontal soil water transport during evaporation is possible to find, but it seems to be more difficult than for water infiltration into the soil, and therefore it will not be discussed here. Below, a short description of the soil water transport is presented, for soil with its upper dry layer.

Analysis of the second stage of evaporation is convenient to start with formulation of the soil surface energy balance equation, and that on the bottom surface of the upper relatively dry soil layer. Here, as it will be used also later, a subscript " denotes soil surface and subscript " 0 " - to the bottom of dry soil layer

$$
\begin{aligned}
& R_{S}=P_{S}+B_{S}, \\
& B_{S}=E_{S 0}+B_{0} .
\end{aligned}
$$

Here $B_{s}$ is heat flux through the bottom surface of the dry layer. Its evident, if (79) will be introduced into (78), the energy balance of soil surface will follow.

To describe the water vapour flux through the upper dry layer of a soil, the following equation can be used

$$
E=\rho \varepsilon m\left(q_{0}-q_{s}\right) / z_{s},
$$

where $q_{s}$ - saturated air humidity at the bottom surface of the dry soil layer, $\varepsilon$ - coefficient of molecullar diffusion of the air water vapour, $m-$ free soil porosity, $z_{s}$ - thickness of the dry soil layer. 
To express equation of heat transport in the soil, the convective and conductive components of a flux are involved. It can be shown, that the first of both plays the dominat role:

$B=M_{S}\left(T_{0}-T_{S}\right) / z_{S}$

$M_{s}=\rho c_{p} a_{k} m+\rho_{s} c_{p} a_{s}(1-m)$,

$\rho$ and $c_{p}$ preserve their meaning, $a_{k}$ - coefficient of convective (molecular) heat conductivity of the air, $a_{s}$ - coefficient of heat conductivity of the solid soil component.

To multiply the both sides of the Eq. (80) by $L$, the equation can be rearranged as $z_{\mathrm{s}} \frac{L E}{m \varepsilon}=L \rho\left(q_{0}-q_{\mathrm{s}}\right)$.

Considering relationship between the saturated air humidity $q_{0}$ and the air temperature $T_{0}$, this relationship can be developed in the exponential series. As a result, from the (82) it can be rearranged into:

$z_{\mathrm{s}} \frac{L E}{m \varepsilon}=L \rho\left[q_{0 m}+\phi^{\prime}\left(T_{0}-T_{2}\right)\right]$.

To add and subtract to the right side of the Eq. (83) (in brackets) $q_{2}$ and $T_{s}$ it can be obtained

$z_{\mathrm{s}} \frac{L E}{m \varepsilon}=L \rho\left[\left(q_{2 m}-q_{2}\right)-\left(q_{\mathrm{s}}-q_{2}\right)+\phi^{\prime}\left(T_{0}-T_{\mathrm{s}}\right)+\phi^{\prime}\left(T_{\mathrm{s}}-T_{2}\right)\right]$.

To rearrange the equation in a way similar to the development analyzing transpiration process, (84) can be rewritten to the form

$$
\begin{aligned}
& z_{\mathrm{S}} \frac{L E}{m \varepsilon}=L \rho d-\left(1+\frac{L}{c_{p}} \phi^{\prime}\right) L \rho\left(q_{s}-q_{2}\right)+ \\
& +\rho c_{p} \frac{L}{c_{p}} \phi^{\prime}\left(T_{0}-T_{S}\right)+L \rho \frac{L}{c_{p}}\left(\theta_{S}-\theta_{2}\right) .
\end{aligned}
$$

To transform the Eq. (85), it is appropriate to multiply both sides of this equation by $D_{s}$ and then to divide it by $1 /\left(1+\frac{L}{c_{p}} \phi^{\prime}\right)$, having in mind, that $b_{1}=1 /\left(1+\frac{L}{c_{p}} \phi^{\prime}\right)$, and $b_{2}=\frac{L}{c_{p}} \phi^{\prime} /\left(1+\frac{L}{c_{p}} \phi^{\prime}\right)$.

Then, using Eqs. (81), and (80), the term containing $T_{0}-T_{s}$ will be evaluated. Doing that, in (81) the term containing coefficient of the soil solid component thermoconductivity, will be neglected. This simplification is fully appropriate at this development stage, because the basic role in the dry soil layer formation plays the convective component, which is much more important than the conductive one. This step is used to simplify the equation and to make it easier to understand. Terms $q$ and $\theta$, are of the same meaning as before.

Performing all the necessary rearrangements, moving all the terms to the left side of the equation, from $(85)$ it can be expressed

$$
\begin{aligned}
& z_{s} L E\left(\frac{b_{1} z_{s}}{m \varepsilon}+\frac{b_{2} z_{s}}{m a_{k}}\right) D_{s}=D_{s} L \rho b_{1} d+ \\
& +b_{2}\left(R_{0}-B\right)+\frac{b_{2} D_{s}}{m a_{k}} B_{0} .
\end{aligned}
$$

It can be easy found, that the first term of the right side of the Eq. (86) is identical to right side of the Eq. (78). It can be indicated as $L E_{s p}$. Then, solving the Eq. (86) according to $L E_{s}$ it can be written

$E_{\mathrm{S}}=E_{s p} /\left(1+\beta_{\mathrm{S}} z_{\mathrm{s}}\right)$

$\beta_{\mathrm{s}}=\left(\frac{b_{1}}{m \varepsilon}+\frac{b_{2}}{m a_{\mathrm{k}}}\right) D_{\mathrm{s}}$.

Here, the term containing $B$, is neglected, because it can be taken as an adjustment to the $B_{s}$, involved in the term $E_{s p}$.

The Eq. (87) is in accordance to the data of measurements, presented in different publications. Some of them are noted in the legend to the Fig. 11. All the experimental results are presented in this figure. Those experiments were performed nearly identically. Cylinders, made of metal, or plastic, were partially filled with soil, then weted, to allow the superfluous water to flow out from the cylinder. Then, upper part of the wetted soil was located to the depth $z_{s}$, and the upper part of cylinder was filled up with an air-dry soil. Evaporation rate $E_{s}$ was evaluated by systematic weighing of the cylinder. $E_{s p}$ was estimated by weighing of the fully saturated soil in another cylinder. Evaluation of $\beta_{s}$ is simple and does not need further comment. 


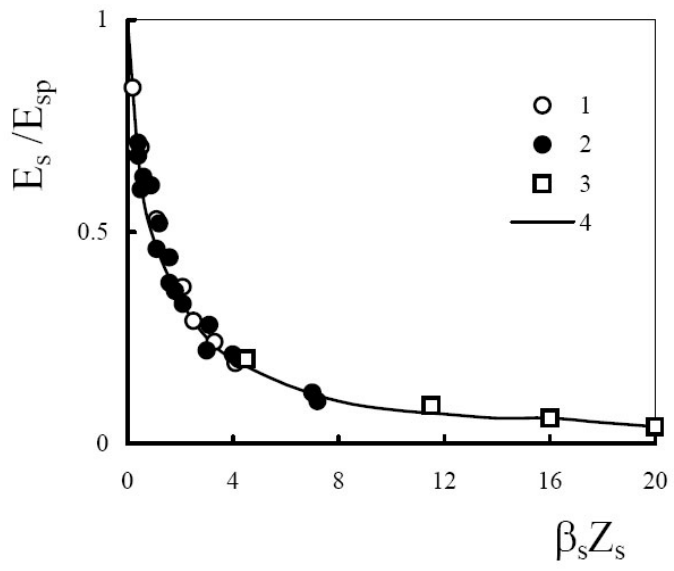

Fig. 11. Relative evaporation of water from soil $E_{s} / E_{s p}$ versus the dry soil layer thickness $\beta_{s} z_{s}$, where $\beta_{s}$ is the empirical coefficient. Results of experiments - (1) Celischeva (1965), (2) Dandaron (1957), (3) Gardner (1957). The curve was calculated according to Eq. (87).

It can be noted, that the term $\beta_{s}$ containing $D_{s}$ does not depend on wind velocity, due to the "Morozow effect" described previously. This phenomenon was demonstrated and confirmed with the example of canopy leaves, by some simple experiments. Those experiments were performed with dry soil layer too, using the before described small wind tunnel. There were used two metal cylinders simultaneously, their cross-section area was $5 \mathrm{~cm}^{2}$. On the top of one of those two cylinders, a dry soil layer of constant thickness was located. At bottom of this dry layer, thermometers were located, to measure temperature. The constant high water content was held in the second cylinder, and thermometers were located at the soil sample surface. Evaporation was estimated by weighing of the cylinders with soil samples. Soil water content at bottom of the dry part of soil sample was saturated, as it should be at the soil surface of the saturated soil. There are two kinds of data allowing to evaluate $D_{s}$; first to evaluate its more complicated analogical term $D_{s}^{*}$. The wind welocity varied from 0 to $3.2 \mathrm{~m}$ $\mathrm{s}^{-1}$. It was found, that relationship between $D_{s}^{*}$ and $D_{s}$ was linear, in all of the experiments performed. It is quite convincing argument of independency of $\beta_{s}$ on the wind velocity and on the $D_{s}$ too. This kind of experiment can be easily repeated.

The dry soil layer water balance equation can be written as

$$
\left(\theta(t)-\theta_{0}\right) \frac{\mathrm{d} z_{S}}{\mathrm{~d} t}=E_{S}(t)-v_{S}(t),
$$

where $\theta(t)$ - water content of the soil, just below bottom of the dry soil layer, $\theta_{0}$ - residual soil water content of it, corresponding to the thin layer of adsorption water, in thermodynamic equilibrium with air humidity of the dry soil layer $q_{0}, v_{s}$ - influx of water to bottom surface of the dry soil layer.

The Eq. (88) have to fullfil the condition $v_{s} \leq E_{s}$ because of the hysteresis phenomenon.

Analysing transport of soil water in during the evaporation process, a deep groundwater table level is being supposed, i.e. groundwater table influence upon the soil water has been neglected. The upper soil layers are usually weted to a depth close to 1 $\mathrm{m}$, depending on type of the season under conditions of the Eastern Europe. In this layer, the soil water content corresponding to a field capacity, is usually established during the autumn - winter periods, following heavy rains or snowmelt. Wet soil layer is of the irregular shape, as it can be observed during an infiltration. This wet soil layer contains water which is in russian literature noted as the "hanged" water.

Diffusion-type mechanism of the unsaturated soil water transport was accepted as an universal one, by majority of the soil scientists. Informations appeared in the literature, showing some facts about non-universality of this soil water transport mechanism in infiltrated soil layers. However, these were considered as some kind of paradox. Those phenomena were not explained succesfully in framework of the existing theory until now. Therefore, a simple empirical relationships can be used, which can be expressed in the form

$v_{s}=\alpha_{s}\left(\theta(t)-\theta_{r}\right)$.

Here $\alpha_{s}$ - empirical parameter, depending on coefficient of the hydraulic conductivity of soil, and soil water potential of the bottom layer of soil, $\theta_{r}-$ soil water content at which soil water transport to the weting front practically stops, $v_{s}$ - soil water transport rate.

The mentioned relationships should be completed with the water balance equation of the "hanged" water layer

$h_{h} \frac{\mathrm{d} \theta}{\mathrm{d} t}=E(t)$

where $h_{h}$ - the thickness of the layer of "hanged" water.

The system of equations describing second stage of the water evaporation by soil is closed, and therefore it can be solved. The solution cannot be 
expressed analyticaly, because of the limitation expressed as $v_{\mathrm{s}}(t) \leq E_{s}(t)$. However, it can be solved numericaly. Results of this solution can express an average daily evaporation totals, i.e. the daily evaporation changes can be estimated. This solution is complicated and not appropriate for practical purposes.

The second stage of evaporation is changing to its third stage, when soil water content of the "hanged" soil water has reached the residual soil water content $\theta_{r}$, and water inflow into the evaporating soil layer is becoming close to zero. To describe this stage of evaporation quantitatively, it is reasonable to use the Eqs. (87) and (88). Evaluating $E_{s}$ from the Eq. (88), the simple differential equation according to $\mathrm{d} z_{s} / \mathrm{d} t$, can be developed and solved for $z_{s}$. Substituting it to the Eq. (87) will solve the problem.

The third stage of evaporation would not be observed in the field, if groundwater table level is in contact with the soil water, usually the first and the second stages take place, and the dry upper layer of soil can be formed too. In this case, determination of the soil water evaporation is becoming more complex. In general, to solve this problem, the soil water balance equation have to be added to the solution, describing interactions between groundwater and the soil water.

At present time, there is not existing and widely accepted physically and physiologically based mathematical evapotranspiration model. Therefore, relatively simple, empirical models are often used, which proved themselves as quite acceptable from a practical point of view. To calculate evaporation for the situation of relatively deep groundwater table location (according to the widely accepted experience, not more than $3-4 \mathrm{~m}$ below the soil surface), the following empirical formula can be used

$E_{s}=E_{s p}\left[\frac{\gamma}{h_{h}}\left(\bar{\theta}-\overline{\theta_{r}}\right) \mathrm{e}^{-H / E_{s p}}+\left(1-\mathrm{e}^{-H / E_{s p}}\right)\right]$.

Here $\gamma$-empirical parameter, evaluated from the field measurements, $h_{h}$ - the "hanged" soil water thickness layer, $H$ - precipitation, $\bar{\theta}$ - average soil water content of the "hanged" soil water layer.

Note, that the Eq. (91) for $H=0$ is in an analogy to formula (90), and for $H \rightarrow \infty$, the first its term is missing, so $E_{s} \rightarrow E_{s p}$. Presence of a single parameter only, simplifies its estimation, using standard observations data. It can be also noted, that precipitation $(H)$, involved in the Eq. (91), as well as the number of precipitation events during the chosen time interval, are important. It should be reasonable to add some correction to this equation. This step seems to be simple, but in practice, it is not easy to materialize.

Formula (91) can be applied to calculate the soil water evaporation below the plant canopy. In this case - without significant error - potential evaporation can be evaluated according to formula

$E_{s p}\left(\omega_{0}\right) \approx R_{s}-B$.

This formula can be used succesfully for low $\omega_{0}$ values. Soil water content $\theta$ can be evaluated using the soil water balance equation, in which even transpiration takes part.

\subsection{Evaporation of the intercepted precipitation}

The third component of evapotranspiration is the evaporation of this part of precipitation, intercepted by the plant canopy. This component, as well as the soil evaporation, is often indicated as the nonproductive part of evapotranspiration.

This statement cannot be accepted, even if it seems to be reasonable. Here are the reasons:

- intercepted precipitation will be evaporated,

- leaves are usually hydrophobic and therefore intercepted water is not covering them continuously, but in the form of water drops,

- leaf parts covered by water are not transpirating .

Solution of this problem leads to evaluation of the difference between evaporation of the water drops (their curvature can be neglected), and the transpiration. Taking into account the previous sentence, to calculate evaporation of the intercepted part $H_{z}$ of precipitation $H$, the following equation can be used

$$
H_{z}=\left(1+\overline{b_{1} p_{0}}\right)^{t} E_{t p} \mathrm{~d} t
$$

where the upper integral boundary is the time interval during which all the intercepted precipitation can evaporate. Transpiration of the leaf part covered by water drops can be expressed by

$$
\int_{0}^{t} E_{t} \mathrm{~d} t=\Phi_{0} \int_{0}^{t} E_{t p} \mathrm{~d} t
$$

Using the Eqs. (93) and (94), difference between the evaporation of intercepted precipitation and transpiration $\Delta H_{z}$ can be estimated by the equation 


$$
\Delta H_{z}=\left(1+b_{1} p_{0}-\Phi_{0}\right) \int_{0}^{t} E_{t p} \mathrm{~d} t .
$$

Then, dividing $\Delta H_{z}$ by $H_{z}, \eta_{t}$ can be expressed as

$$
\eta_{t}=1-\Phi_{0} /\left(1+\overline{b_{1} p_{0}}\right) .
$$

The term $\Delta H_{z}$ is one of the evapotranspiration components. Remaining part of the intercepted water is decreasing transpiration, and thus decreasing also the soil water uptake by the plant. This is the important ecological role of the intercepted water. The role of interception is accented particularly by the fact - well known to agrometeorologists - precipitation totals lesser than $5 \mathrm{~mm}$, are supposed to be "non-productive". That precipitation is wetting the upper soil layer, dried only periodically, not containing the root hairs. It can be noted, according to data characterising precipitation in the European part of Russia, that daily precipitation lesser than $5 \mathrm{~mm}$, are participating approximately in some $40 \%$ of the monthly precipitation totals (Budagovskyi, 1964).

\subsection{Evaporation measurement methods}

Parameters of the transpiration models can be estimated using data from direct measurements of transpiration fluxes. Methods, suitable for the direct measurements of vater vapour fluxes should average them in time intervals $20-30$ minutes. A small number of methods can be used to estimate the data, usable for the above mentioned purposes.

As the most suitable is considered so far the eddy correlation method. Its principle is characterized by the equations, describing the turbulent heat and the water vapour transport:

$$
\begin{aligned}
& E=\rho \overline{w^{\prime} q^{\prime}}, \\
& P=c_{p} \rho \overline{w^{\prime} T^{\prime}},
\end{aligned}
$$

where $w^{\prime}$ - instantaneous fluctuation of the wind velocity vertical component, i.e. the deviation from its mean value equal to zero, $q^{\prime}$ and $T^{\prime}$ are instantaneous fluctuations of the air humidity and the air temperature from their mean values, respectively. Eqs. (97) and (98), without signs of averaging, are expressing the instantaneous water vapour and heat fluxes. Actual meaning of these equations is expressing average fluxes during periods of their averaging.
At present time, there is existing equipment, enabling us to measure values of characteristics $w$ and $T$, and of their eddies, nearly at points. Typical dimension of such a sensor for $w$ measurement, is approximately of $2,5 \mathrm{~cm}$ diameter, and of such for $T$, about $1 \mathrm{~cm}$. Sensor for the air humidity measurement is somewhat larger.

Eqs. (97) and (98) are of a proper theoretical base, but their application techniques needs verification. For that, it is sufficient to use the energy balance equation, in the form

$$
L E+P=R-B \text {. }
$$

On the horizontal axis of the graph, the right side of the Eq. (99) can be plotted, on the vertical graph axis, values of the left side of this equation. Significant dispersion of points is usually observed and points are usually grouped below the axis of symetry. Different reasons of this effect were presented until now. To explain this phenomenon, we can try to use other known facts. Measurement of the latent heat $(L E)$, and of the sensible heat $(P)$ fluxes by the eddy correlation and energy balance methods were performed in framework of the international experiment (KUREX - 88). Several methods were compared for the evapotranspiration estimates. Measurements took place at Kursk Experimental Station, Soviet Academy of Sciences, in 1988. Measurement results by two methods are presented in Figs. 12a) and 12b). Values $L E$ and $P$ expressed in $\mathrm{W} \mathrm{m}^{-2}$, were estimated by the energy balance method, and are presented on the horizontal axis, on the vertical one are results estimated by the eddy correlation method. It is important to note similarity of the latent heat fluxes relationship with interrelation of the $L E+P$ and the $R-B$. Points in the Fig. 12b) are grouping closely along the coordinate axis of symmetry, and their dispersion (considering the different scales of Figs. 12a) and 12b)) is comparable to errors of the measurement by the energy balance method. Reasons for such phenomena is in generation of the small-scale turbulency by the plant canopy. This phenomenon was discussed by Budagovskyi (1981), but his results were not utilised later. Therefore, it seems to be reasonable, to explain this fact briefly.

Plant canopy is not a homogeneous body, but an object, composed of a more discrete parts. Therefore, sun radiation is absorbed by the leaves and by their parts only. Leaves absorbing direct radiation are shading other leaves, absorbing only scattered indirect radiation of the lower intensity. The different energy absorption causes different 
leaves temperatures which leads to the local convective air transport. Conductive fluxes in both vertical directions can be observed, probably even effect of colder air "trickle down" along the leaves. Convective fluxes of elementary air mass volumes could lead to the compensating air fluxes in different directions in the inter-leaves air space, and to the resulting small-scale turbulence. This kind of turbulence can propagate into boundary air layer,

a)

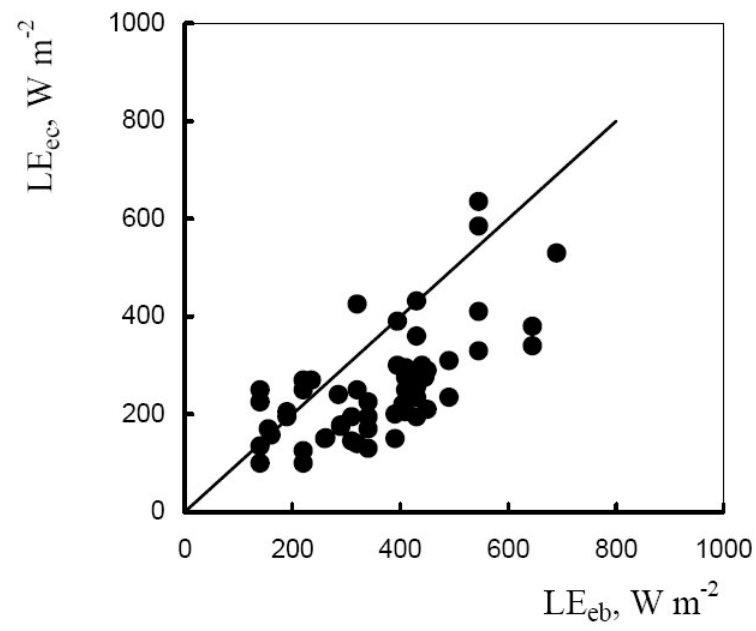

next to the canopy. This kind of processes should take place even during the night time, due to mutual shadoving of the leaves.

There are indirect informations for supporting this idea. First of them, results from the $q(z), T(z)$, $R(z)$ measurements, in the different air layers above the ground. Method of this kind of measurements is briefly described in the literature (Budagovskyi,

b)

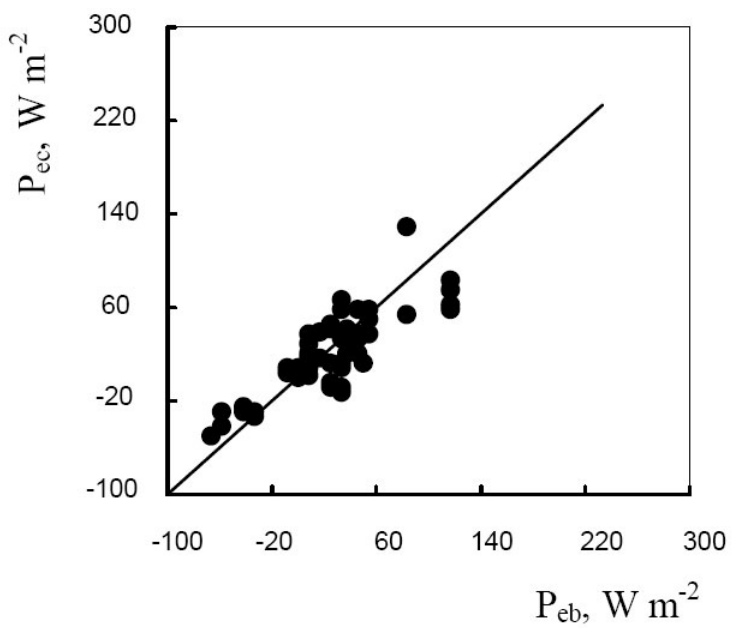

Fig. 12. Relationships between (a) latent heat $L E$ and (b) sensible heat $P$ fluxes, estimated by the energy balance (subscript eb) and eddy correlation (subscript ec) methods.

Lozinskaya, 1997; and Budagovskyi, Lozinskaya, 1998). The data from measurements were used to calculate coefficients of turbulence, at any layer where these measurements were performed. The $k$ values at the plant canopy surface $(z=h)$, were usually more than of the three ordres higher, as were values of the turbulence coefficients in the atmosphere $(\varepsilon)$. According to the existing theory $k$ $\rightarrow \varepsilon$, above the solid surface, represented by a bare soil, which is not expected by the theory. It should be expected therefore, that the discussed smallscale turbulence plays an important role in the latent and the sensible heat transport within the plant canopy, and above it, as well.

The second indirect argument to explain the discussed phenomenon, are data acquired during the measurement of energy balance structure in years 1955-1957, in the central part of Fergana Valley (Golodnaya step, Russian Central Asia). Wind velocities below sensitivity limit of the anemometers used $\left(0,3-0,4 \mathrm{~m} \mathrm{~s}^{-1}\right)$ were measured there, when net radiation was extremely high. Stratification of the air density for clearly expressed temperature inversion - calculated according to Zilitinkievic (1970) was always stable. That information demonstartes the plant canopy turbulence production, and it should be of a small-scale.

Results of the heat balance estimation by eddy correlation techniques agrees quite well with data estimated by the heat balance method, but such an agreement for latent heat comparison was not met. The reason can be in small dimensions of the used sensors, to measure necessary data for the heat transport observation. It can be noted, that sensors for the air humidity eddies measurement are relatively large in comparison to small sensors for the air temperature and the wind velocity measurements. Those "large" sensors probably cannot measure pulsations casused by a small-scale turbulence in a plant canopy. This statement can be easily verified by series of the eddy correlation method measurements above the fairly wet bare soil surface. Above this surface, generation of the smallscale turbulence is not probable.

Application of the Eq. (98) leads to quite satisfactory results. Design of the small scale sensors to measure eddies of the air humidity, is not probable in the near future. Therefore, it seems to be a good 
way to calculate latent heat fluxes by use of the Eq. (99), in the form

$$
L E=R-B-P \text {. }
$$

The discussed idea is not new, it can be indirectly found in publication of Monin and Yaglom (1965). In the same work, the problem is mentioned of the soil heat flux $B$ estimation. It is assumed to be of a small reliability, due to technical problems, related to its measurement. This opinion is probably due to the methods of $B$ calculation, in which classical forms of the heat transport equation solution were utilized. In this solution, the empirically estimated relationship between the heat conductivity coefficient and the soil water content was used. Their distribution in the soil profile was estimated, using the existing simplifications too. Application of the such kind heat transport evaluation in the soil is not reliable. To overcome the mentioned difficulties, the heat balance approach can be used. This approach needs application of the following equation, with some simple rearrangements

$$
\frac{\partial B}{\partial z}=C_{s}^{*} \frac{\partial T_{s}}{\partial \mathrm{t}} ; \quad C_{s}^{*}=\rho_{s}\left(C_{s}+C_{w} w\right)
$$

where $C_{S}^{*}$ - heat capacity of a wet soil on the volume basis, $\rho_{s}$ - dry soil density, $C_{s}$ - specific heat capacity of the solid soil component, $C_{w}-$ specific heat capacity of water, $w$ - soil water content expressed in the mass units (the mass of water per unit mass of a dry soil), $z$ - vertical coordinate, positive downward from the soil surface, $t$ - time, $T_{s}$ - soil temperature.

Let us integrate (101) according to $z$ from $z=0$ (soil surface) up to the depth $z$, at which daily changes of the soil temperature are observable. This depth is usually between $40-50 \mathrm{~cm}$.

$$
B(0)=\int_{0}^{z} C_{S}^{*} \frac{\partial T_{S}}{\partial t} \mathrm{~d} z
$$

The term $C_{s}$ is changing in a very narrow range for mineral soils, therefore it can be taken as its mean value. Methods of $\rho_{s}, w$ and $T_{s}$ estimation are well known, and need not special comment.

Accepted assumptions, enabling to utilize the mean values of $\rho_{s}$ and $w$ along the soil depth, lead to the simple relationship

$$
B(0)=\frac{\mathrm{d}}{\mathrm{d} t} \int_{0}^{z} C_{S}^{*} T_{S} \mathrm{~d} z
$$

Results of $B(0)$ calculation by the Eqs. (103) and (102), have shown a negligible differences between them.

Presented method of the latent turbulent fluxes estimation can be - quite reasonable - indicated as the "complete" method.

Method of the turbulent fluxes estimation, based on vertical profiles of the air temperature, of the air humidity and of the wind velocity mesurements, is often called the gradient method. This method - its theory and methods of its application are fully described by Monin and Yaglom (1965). This method is important especially in research of the atmosphere boundary layer. But its application for the evapotranspiration model parameters estimates is not easy, because of its sensitivity to the air humidity profiles determination. To take correct data from measurements it is necessary to measure $T, q$ and $u$, up to the height of $16 \mathrm{~m}$, with minimum up to $8 \mathrm{~m}$. In addition, only a properly trained and qualified personnell should be engaged in the measurements.

In framework of the problems discussed here, the energy balance method is used very frequently. This method utilizes the Eq. (99), together with the equation describing sensible and latent heat fluxes between the heights $z_{1}$ and $z_{2}$

$$
\begin{aligned}
& L E=L \rho D_{v}\left(q_{1}-q_{2}\right), \\
& P=\rho c_{p} D_{t}\left(T_{1}-T_{2}\right) .
\end{aligned}
$$

Here $D_{v}$ and $D_{t}$ are integral coefficients of the water vapour turbulent transport, and of the heat transport, between heights $z_{1}$ and $z_{2}$. In this method, the assumption $D_{v}=D_{t}$ is applied. This leads usually to acceptable results of calculation, but from theory it follows, that this approximation is not valid generally. Evaluation of differences between the estimated fluxes using an approximation, and the exactly estimated coefficients is needed. A simple, fully acceptable method can be proposed. It is based on application of the above described "complete" method to estimate $P$ and $L E$, with additionally measured differences $q_{1}-q_{2}$, and $T_{1}-T_{2}$.

Using the Bowen ratio $\mathrm{Bo}$, it can be written

$$
\frac{P}{L E}=\frac{D_{t} c_{p}\left(T_{1}-T_{2}\right)}{D_{v} L\left(q_{1}-q_{2}\right)} \text {. }
$$

The difference $\left(1-D_{t} / D_{v}\right)$ can be easily estimated, with sufficient measured values, needed in Eq. (106). However, until now - according to our knowledge - there are not such data beeing used to verify this difference. Numerous undirect data indi- 
cated the small differences between $D_{t}$ and $D_{v}$. Simultaneous solution of the Eqs. (99), (104) and (105), assuming $D_{t}=D_{v}$, leads to the following equation

$$
\begin{aligned}
& L E=(R-B)\left(q_{1}-q_{2}\right) /\left(\theta_{1}-\theta_{2}\right) ; \\
& \theta=q+\frac{c_{p}}{L} T .
\end{aligned}
$$

Standard application of the described method needs use of a standard equipment, like the aspiration psychrometer of usual size, thermoelectric net radiometer, anemometers, resistance thermometers (sometimes mercury thermometers), to measure the soil temperature. Soil heat fluxes are calculated by the formula (102) or (103). In principle, in measurement further technical improvement are not fully utilized until now. However, there are not new, highly precise data to improve our understanding of this phenomenon yet. To estimate reliable data, it is necessary to fulfill some serious requirements, briefly described by Budagovskyi (1989) in his description of the measurement scheme. They will not be repeated here, but a short technical note will be given. Usually, results of measurement are used to be drawn in the semilogarithmic scale, in which the air temperature and the air humidity are drawn in relation to heights $z$, at which those data were measured. Calculating the average differences $q$ and $T$, some problems are often met. To overcome difficulties of this kind, relationships $q=f(\theta)$, and $T=f(\theta)$, should be drawn also. Those relationships are linear, and tangent of the first relationship slope by $R-B$ equals $L E$. Product of the second relationship slope and of the $R-B$, equals to $P$. Criterion of the energy balance consistency is equality of the both lines tangents sum.

There is a considerable quantity of experimentally estimated data acquired by using of the relatively simple energy balance method, which can be used to evaluate parameters of the transpiration models. Utilisation of this method is limited to the low canopies. Even its application to low forest canopies is technically complicated. The so called "complete" method of evapotranspiration estimation could be easier to apply, but it is not developed in details until now.

There is a huge quantity of the canopy types on the Earth, but evaluation of the transpiration model parameters is difficult, even for the most important of them. Therefore, the question has arosen about their remote sensing estimates, including satelite informations. This idea is not new, but its not ap- plied satisfactorily. At that time, the work of Budagovskyi and Lozinskaya (1996) can be noted. There are published empirical relationships between $T_{0}$ $T_{2}$ and $T_{l}-T_{2}$, as well as $q_{0}-q_{2}$ and $q_{1}-q_{2}$, in which $T_{0}$ and $q_{0}$ are the air temperature and the air humidity at the canopy surface, respectively. Further on, $T_{l}$ - leaf temperature, $q_{l}$ - saturated air humidity in the leaf mesophyll at $T=T_{l}$. Relationships are linear and close, but there is not a reason to expect the proportionality coefficients universality. Problem of the analytical relationship development has arisen, in which the $T_{l}$, and $q_{l}$ as the input data would be used. Such development has been made, but it was not yet published. It is so because it contains transport coefficients, difficult to evaluate. Further studies seem to be necessary, of the empirical relationships of this type. The activities in this direction led to the relationship, formally analogical to (107). The equation below, led to acceptable results, containing only one correction coefficient, with its value close to unity

$$
\begin{aligned}
& L E=g\left(q_{1}-q_{2}\right) /\left(\theta_{1}-\theta_{2}\right) ; \\
& \theta_{1}=\left(q_{1}-q_{2}\right)+\frac{c_{p}}{L}\left(T_{1}-T_{2}\right) .
\end{aligned}
$$

Correction coefficient $g$ was estimated by using data from the field experiments, in which $T_{l}$ was measured by the portable radiation thermometer. Using those measurements, the value of $g=1.15$ was estimated, correlation coefficient between values of $L E$, calculated by the formula (107) and (108) was estimated as 0.96 , coefficient of variation of the differences $L E$ series according to previously given formulae, equals to 0.26 .

To calculate $g$, series of data just above fifty was used, as they were estimated by measurement in canopies of wheat, maize and buckwheat (Polygonum sativa). Important is the variation of $\Phi_{0}$, in the range of 1 to 0.42 .

Results presented are promising and research in this field should be continued. Results of research involving influence of the different evaporating surfaces on evaporation can be utilised in future, for spatial variability evaluation of the water and energy transport between the evaporating surface and boundary layer of the atmosphere.

$$
\begin{aligned}
& \text { List of symbols } \\
& \begin{array}{l}
A-\text { area }\left[\mathrm{L}^{-2}\right], \\
B-\text { soil heat flux }\left[\mathrm{L}^{2} \mathrm{M} \mathrm{T}^{-2}\right], \\
C_{\mathrm{S}}^{*} \text { - specific heat capacity of a wet soil }\left[\mathrm{L}^{2} \mathrm{~T}^{-2} \mathrm{~K}^{-1}\right],
\end{array}
\end{aligned}
$$


$C_{w}$ - water specific heat capacity $\left[\mathrm{L}^{2} \mathrm{~T}^{-2} \mathrm{~K}^{-1}\right]$,

$C_{s}$ - specific heat capacity of the solid fraction of soil $\left[\mathrm{L}^{2} \mathrm{~T}^{-2}\right.$ $\left.\mathrm{K}^{-1}\right]$,

$D_{l}$ - water vapour conductivity between leaf and its environment $\left[\mathrm{L} \mathrm{T}^{-1}\right]$,

$D_{t}$ - heat conductivity between leaf and its environment $\left[\mathrm{L} \mathrm{T}^{-1}\right]$,

$D_{0}$ - turbulent conductivity of air layer between levels $z_{1}$ (the top of the canopy) and $z_{2}\left[\mathrm{~L} \mathrm{~T}^{-1}\right]$,

$E_{t}-$ transpiration rate $\left[\mathrm{L}^{3} \mathrm{~L}^{-2} \mathrm{~T}^{-1}\right]$,

$E_{t p}$ - potential transpiration rate $\left[\mathrm{L}^{3} \mathrm{~L}^{-2} \mathrm{~T}^{-1}\right]$,

$E$ - evapotranspiration rate $\left[\mathrm{L}^{3} \mathrm{~L}^{-2} \mathrm{~T}^{-1}\right]$,

$E_{l p}$ - leaf transpiration at optimal leaf water content (potential transpiration) $\left[\mathrm{L}^{3} \mathrm{~L}^{-2} \mathrm{~T}^{-1}\right]$,

$E_{l}$ - transpiration from the unit of leaf area $\left[\mathrm{L}^{3} \mathrm{~L}^{-2} \mathrm{~T}^{-1}\right]$,

$E_{p}$ - potential evapotranspiration rate $\left[\mathrm{L}^{3} \mathrm{~L}^{-2} \mathrm{~T}^{-1}\right]$,

$E_{s p}$ - potential evaporation rate $\left[\mathrm{L}^{3} \mathrm{~L}^{-2} \mathrm{~T}^{-1}\right]$,

$E_{s}$ - soil evaporation rate $\left[\mathrm{L}^{3} \mathrm{~L}^{-2} \mathrm{~T}^{-1}\right]$,

$H$ - precipitation $\left[\mathrm{L}^{3} \mathrm{~L}^{-2}\right]$,

$I_{a}$ - longwave radiation of the atmosphere $\left[\mathrm{L}^{2} \mathrm{M} \mathrm{T}^{-2}\right]$,

$I_{e}$ - long wave radiation balance $\left[\mathrm{L}^{2} \mathrm{M} \mathrm{T}^{-2}\right]$,

$I_{l}$ - long wave emission of the land surface $\left[\mathrm{L}^{2} \mathrm{M} \mathrm{T}^{-2}\right]$,

$K_{p}$ - integral hydraulic conductivity of a canopy $\left[\mathrm{L}^{3} \mathrm{~L}^{-2} \mathrm{~T}^{-1}\right]$,

$L$ - latent heat of evaporation $\left[\mathrm{L}^{2} \mathrm{~T}^{-2}\right]$,

$P \quad$ - sensible heat flux $\left[\mathrm{L}^{2} \mathrm{M} \mathrm{T}^{-2}\right]$,

$R$ - net radiation $\left[\mathrm{L}^{2} \mathrm{M} \mathrm{T}^{-2}\right]$

$R_{0}-$ net radiation at the top canopy level $\left[\mathrm{L}^{2} \mathrm{M} \mathrm{T}^{-2}\right]$,

$T$ - air temperature $\left[{ }^{\circ} \mathrm{C}\right]$,

$T_{*}$ - scaling parameter for air temperature,

$T_{l}$ - leaf temterature $\left[{ }^{\circ} \mathrm{C}\right]$,

$T_{2}$ - air temperature at height $z_{2}\left[{ }^{\circ} \mathrm{C}\right]$,

$V$ - volume $\left[\mathrm{L}^{3}\right]$,

$c_{p}-$ specific heat capacity of air at constant pressure $\left[\mathrm{L}^{2} \mathrm{M} \mathrm{T}^{-2}\right.$ $\left.\mathrm{K}^{-1}\right]$,

$d-$ air humidity deficit [-],

$h$ - hydraulic head [L],

$k$ - coefficient of turbulent transport $\left[\mathrm{M}^{2} \mathrm{~T}^{-1}\right]$,

$l$ - length of an element under study in the direction of wind speed [L],

$q$ - absolute air humidity [-],

$q_{*}$ - scaling parameter for absolute air humidity,

$q^{\prime}$ - instantaneous fluctuations of absolute air humidity [-],

$q_{l}$ - saturated absolute air humidity in inter-cells leaf space $[-]$,

$r_{a}$ - canopy aerodynamic resistance $\left[\mathrm{T} \mathrm{L}^{-1}\right]$

$r_{s}$ - stomata resistance $\left[\mathrm{T} \mathrm{L}^{-1}\right]$,

$v \quad$ - kinematic viscosity $\left[\mathrm{L}^{2} \mathrm{~T}^{-1}\right]$,

$v_{l}$ - water content per unit leaf area $\left[\mathrm{L}^{-2}\right]$,

$v_{l}^{*}$ - dimensionless leaf water content $[-]$,

$v_{p}$ - rate of water flow from soil to the plant leaves $\left[\mathrm{L}^{3} \mathrm{~L}^{-2} \mathrm{~T}^{-1}\right]$

$w^{\prime}$ - instantaneous fluctuations of the vertical component of wind speed $\left[\mathrm{L} \mathrm{T}^{-1}\right]$,

$z$ - vertical coordinate [L],

$\alpha$ - albedo [-],

$\varepsilon$ - thermal emisivity [-],

$\rho-$ air density $\left[\mathrm{M} \mathrm{L}^{-3}\right]$,

$\rho_{\mathrm{s}}-$ dry soil density $\left[\mathrm{M} \mathrm{L}^{-3}\right]$,

$\sigma$ - Stefan - Boltzmann constant $\left[\mathrm{M} \mathrm{T}^{-3} \mathrm{~K}^{-4}\right]$,

$\chi$ - von Kármán constant [-],

$\psi_{l}$ - leaf water potential [L],

$\psi_{r}$ - water potential at the surface of root hairs [L],

$\psi_{w}$ - soil water potential [L], $\omega(z)-$ leaf area index as a function of $z[-]$,

$\omega_{0}-$ leaf area index [-].

\section{REFERENCES}

BUDAGOVSKYI A.I., 1955: Infiltration of water into soil. (In Russian.) Moscow, Nauka Publ. House, pp.139.

BUDAGOVSKYI, A.I., 1964: Soil water evapotranspiration. (In Russian.) Moscow, Nauka Publ. House, pp. 244.

BUDAGOVSKYI A.I., 1981: Soil water evapotranspiration. (In Russian.) In: Physics of soil water, (Budagovskyi, A.I. Ed.), Moscow, Nauka Publ. House, 13-92.

BUDAGOVSKYI A.I., GOLUBAS T.J., 1994: The influence of water in plant production process. (In Russian with English summary.) Vodnyje resursy, 21, 2, 133-143.

BUDAGOVSKYI A.I., 1989: Semiempirical theory of transpiration and plant canopy water regime. (In Russian with English summary.) Vodnyje resursy, 2, 5-17.

BUDAGOVSKYI A.I., LOZINSKAYA E.A., 1996: Heat and water transport in a canopy. (In Russian with English summary.) Vodnyje resursy, 23, 6, 658-667.

BUDAGOVSKYI A.I., LOZINSKAYA E.A., 1997: The influence of geophysical and biophysical parameters on transpiration. (In Russian with English summary.) Vodnyje resursy, 24, 4, 389-397.

BUDAGOVSKYI A.I., LOZINSKAYA E.A., 1998: Semiempirical theory of evapotranspiration. (In Russian with English summary.) Vodnyje resursy, 25, 5, 562-570.

CELICHEVA L.K., 1965: The influence of dry soil layer thickness and free porosity on evaporation. (In Russian with English summary.) Pochvovedenie (Russian Soil Sci.), No. 3.

DANDARON Ž. D., 1957: The influence of evaporation rate on the dry soil layer thickness. (In Russian.) In: Trudy Burjat-Mongolskovo zoovet. In-ta. V.11.

GARDNER W.R., 1957: Some steady-state solutions of the unsaturated moisture flow equation with application to evaporation from a water table. Soil Sci., 85, No. 4.

GUSEV E.M., 1981: Experimental study of the pressure infiltration. (In Russian.) In: Physics of soil water, (Budagovskyi, A.I. Ed.), Moscow, Nauka Publ. House, 195-205.

KOSSOVICH P.S., 1904: Water properties of soils. (In Russian.) Žurnal opytnoj agronomii, v. 2-3.

MONIN A.S., JAGLOM A.M., 1965: Statistical hydromechanics. (In Russian.) Moscow, Nauka Publ. House, pp. 646.

NOVAK V., 1981a: Transport of soil water during evaporation. (In Russian.) In: Physics of soil water, (Budagovskyi, A.I. Ed.), Moscow, Nauka Publ. House, 160-180.

NOVAK V., 1981b: Evapotranspiration structure. (In Slovak with English abstract.) Vodohospodarsky casopis., 29, 5, pp. 475-490.

PENMAN H.L., 1948: Natural evaporation from open water, bare soil and grass. Proc. Roy. Soc. London, Sect. A, vol. 193, No. 1, 120-145

PHILIP J.R., VRIES D.A., 1957: Moisture movement in porous materials under temperature gradients. Trans. Amer. Geophys. Union, 38, pp. 222-232.

ZILITINKIEVIC S.S., 1970: Dynamics of the boundary layer of atmosphere. (In Russian.) Leningrad, Gidrometizdat Publ. House, pp. 291.

Received 21 May 2010 Accepted 23 June 2010 